\title{
Ailevi Akdeniz ateşi tanısı alan 186 olgunun klinik semptom ve $M E F V$ geni mutasyonlarının incelenmesi
}

\author{
Evaluation of the MEFV gene mutations and clinical symptoms in186 patients diagnosed as \\ familial Mediterranean fever
}

\author{
Mahmut Abuhandan', Cemil Kaya1, Ahmet Güzelçiçek ${ }^{2}$
}

\section{ÖZET}

Amaç: Bu çalışmada Ailevi Akdeniz Ateşi (AAA) tanısı alan ve MEFV mutasyon testi yapılan 186 hastanın retrospektif olarak semptom ve mutasyon oranı tespiti amaçlanmıştır.

Yöntemler: Ailesel Akdeniz Ateşi tanısıyla izlenen 186 hastanın yaşı, cinsiyeti, geliş yakınmaları, aile öyküleri ve MEFV mutasyon testi durumlarını geriye dönük olarak değerlendirmeye alındı. MEFV geni 1. - 10. ekzonlar PCR yöntemi ile amplifiye edildikten sonra DNA dizi analizi ile çalışıldı.

Bulgular: Hastaların 84'ü erkek, 102'si kız olup yaş ortalaması 9,45 \pm 4,40 (yaş aralığı: 2-17) yıl idi. Olguların $\%$ 26,9' unun anne baba arasında yakın akrabalık ve \% 25,8'inin ailelerinde AAA öyküsü vardı. Sıklık sırasına göre başvuru nedenleri karın ağrısı, (\%92,5), ateş $(\% 89,2)$ ve eklem ağrıları $(\% 24,2)$ yer aldı. Tespit edilen mutasyonlar sıklık sırasına göre R202Q (\% 33,3), M694V (\%22,6), E148Q (\% 22), V726A (\%7,5), R761H $(\% 4,3)$, M680I $(\% 3,8)$ ve diğerleri $(\% 6,5)$ genotipi mutasyonlar olarak belirlendi. Hastaların \% 21,5 homozigot ve $\% 67,7$ 'si heterozigot ve \%10,8'inde birleşik heterozigot AAA mutasyonu saptandı.

Sonuç: AAA, Ülkemizde sık görülen ve ayrıcı tanıda güçlük yaşanan bir hastalıktır. Son yıllarda AAA tanısında moleküler genetik yöntemler önem kazanmıştır. Bu çaışmanın sonuçları AAA'lı hastalarda MEFV gen mutasyonundaki heterojeniteyi desteklemiş ve hastalarımızın geniş bir mutasyon yelpazesine sahip olduğunu göstermiştir.

Anahtar kelimeler: Ailesel Akdeniz ateşi, MEFV gen mutasyon, semptom

\section{ABSTRACT}

Objective: This retrospective study aimed to evaluate the clinical symptoms and the MEFV mutation ratios of the 186 patients diagnosed as Familial Mediterranean Fever.

Methods: Age, sex, admission symptoms, family history, and the MEFV mutation test cases of the 186 patients followed as Familial Mediterranean Fever were evaluated retrospectively. MEFV gene was analyzed with DNA sequence analysis after amplifying the exons 1.-10. using PCR method.

Results: There were 84 male and 102 female in the study, and the mean age was $9.45 \pm 4.40$ years. $26.9 \%$ of the patients had close relationship between the parents, and $25.8 \%$ had a family history of AAA. The most common symptoms were abdominal pain $(92.5 \%)$, fever $(89.2 \%)$ and arthralgia $(24.2 \%)$ respectively. The most common mutations were R202Q (33.3\%), M694V (22.6\%), E148Q (22\%), V726A (7.5\%), R761H (4.3\%), M680I (3.8\%), and the others $(6.5 \%)$ respectively. $21.5 \%$ homozygous, $67.7 \%$ heterozygous, and $10.8 \%$ compound heterozygous mutations of AAA were detected.

Conclusion: FMF is a common disease in our country and has difficulties in the differential diagnosis. In recent years molecular genetically methods are considered more commonly for the diagnosis. The results of this study showed that our AAA patients have a wide range of mutations, and supported the heterogeneity of MEFV gene mutations in AAA.

Key words: Familial Mediterranean fever, MEFV gene mutation, symptom

\section{${ }^{1}$ Harran Üniversitesi Tıp Fakültesi, Çocuk sağllğg ve Hastalıkları ABD Şanlıurfa, Türkiye \\ ${ }^{2}$ Şanlıurfa Çocuk Hastanesi Şanlıurfa, Türkiye \\ Yazışma Adresi /Correspondence: Mahmut Abuhandan,}




\section{GíRiş}

Ailesel Akdeniz Ateşi (AAA) periyodik karın ağrısı, ateş ve eklem ağrısına yol açan seröz membranların tekrarlayan inflamatuar ataklarıyla kendini sinırlayan ve sebebi tam bilinmeyen otozomal resesif bir hastalıktır [1]. Atakların süre ve sıklığ 1 kişiden kişiye değişiklik göstermekle birlikte atak süresi 12-96 saat, sıklığı ise haftada bir ile yılda bir arasında değişebilmektedir. Atak esnasında lökositoz, yüksek sedimentasyon hızı, artmış fibrinojen ve C reaktif protein gibi akut faz reaktanları belirgindir. Ataklar arasında hastaların hiç bir şikâyeti yoktur [2,3].

AAA Doğu Akdeniz kökenli topluluklarda özellikle Yahudiler, Türkler, Ermeniler ve Araplar'da sık görülen bir hastalıktır [4]. AAA etiyolojisinde rolü olan $M E F V$ geni 16. kromozomun k1sa kolunda yer aldığ 1 gösterilmiştir [5,6] Bu gen, 781 aminoasitten oluşan pirin/marenostrin adı verilen proteini kodlar [5]. Nükleusta bulunan bu proteinin antiienflamatuvar etkisi olduğu düşünülmektedir [7] Böylelikle $M E F V$ genindeki herhangi bir mutasyon, anormal pyrin proteinlerinin sentezine neden olarak, enflamasyonun etkin olarak baskılanmasını engellemektedir. Ancak yine de atağı başlatan fizyolojik etmenler bilinmemektedir [8]. $M E F V$ geni 10 ekzon içeren büyük bir gen olmasına rağmen mutasyonlar özellikle 10. ekzonda toplanmıştır [9]. $M E F V$ geninde şimdiye kadar yaklaşık 50 mutasyon tanımlanmıştır [10]. Bu genin tanımlanması hastalığın anlaşılması ve tedavisinde bir kilometre taş1 olmuştur [5,6].

Bu çalışmada Ailevi Akdeniz Ateşi tanısı alan ve $M E F V$ mutasyon testi yapilan 186 hastanın retrospektif olarak demografik verileri, semptomlar1 ve mutasyon oranı taranması amaçland.

\section{YÖNTEMLER}

Genel pediatri polikliniğine tekrarlayan karın ağrısı, eklem ağrısı ve ateş gibi semptomları olan çocuklar çalışmaya dahil edildi. Çalışmaya alınan hastaların detaylı fizik muayenesi ve laboratuvar (hemogram, biyokimyasal tetkikler, tam idrar tetkiki ve batın ultrasonografi) incelemeleri yapıld1. Semptomlarını açıklayıcı neden bulunmayan hastalarda AAA düşünüldü ve bu hastalardan AAA mutasyon analizi istendi. Mutasyon analizi pozitif çıkan 186 hasta retrospektif olarak demografik özellikleri (yaş, cin- siyet, akraba evliliği, aile de AAA hikayesi gibi), pedigri analizleri ve klinik verileri toplandı. Çalışma için Harran Üniversitesi Tıp Fakültesi Etik kurulunun onay1 alınd1.

\section{Kan incelemesi}

Tekrarlayan karın ağrısı, eklem ağrısı ve atralji nedeniyle getirilen hastalardan çalışmanın başında otomatik kan sayımı cihazı (Abbot Celldyn 3500 Ill, USA) ile tam kan sayımları, eritrosit sedimantasyon hızı ve creaktif protein düzeylerinin ölçülmesi yapıld1. Araştırma için seçilen vakalardan alınan kan örnekleri 3500 rpm'de 10 dakika santrifüj edildikten sonra şekilli elemanlar tüp ile birlikte atıldı ve kalan serum örnekleri ile elektolitler, böbrek ve karaciğer fonksiyon testleri (Abbott Aeroset, Abbott Diagnostics, Abbott Park, IL, USA) çalışıldı. Ayrıca hastaların tam idrar tetkiki ve batın ultrasonografiler yapılarak normal olduğu tespit edildi.

\section{Gen mutasyon analizi}

Hastaların EDTA'lı tüplere 2 - 5 mL kan alındıktan sonra tıbbi genetik laboratuara; genetik analiz için $18-24^{\circ} \mathrm{C}$ sicaklikta transfer edildi. $M E F V$ geni 1. 2. 3. 4. 5. 6. 7. 8. 9. 10. ekzonlar1 PCR yöntemi ile amplifiye edildikten sonra DNA dizi analizi ile çalışılmıştır. Puregene DNA Isolation Kit (Gentra Systems Inc, Minnea polis, MN, USA) kullanılarak genomik DNA'ları elde edildi. Her DNA örneği için spektrofotometre (Nanodrop ND-100) ile miktar ve saflık tayini yapıldı. DNA örneklerin de PRONTO FMF Kit (Pronto Diagnos tics Ltd., Rehovot, Israel) yardımıyla $M E F V$ gen analizleri gerçekleştirildi.

\section{İstatistiksel analizler}

SPSS (Statistical Package for the Social Sciences, version 11.5 for Windows, SPSS ${ }^{\circledR}$ Inc, Chicago, IL) istatistik analizi programı kullanıldı. Sonuçlar sıklik ve ortalama \pm standart sapma (SD) olarak verildi. Parametrelerin arasındaki ilişkiyi değerlendirmek için ise sperman korelasyon analizi yapıldı. $P$ değeri 0.05 den küçük olanlar istatistiksel olarak anlamlı kabul edildi.

\section{BULGULAR}

Çalışmaya dahil edilen 186 AAA hastanın \% 45,2'si $(\mathrm{n}=84)$ erkek , \% 54,8'i (n=102) kız idi. Çalışmaya 
alınan tüm hastaların yaş ortalaması $9,45 \pm 4,40 \mathrm{y} 11$ (2-17) yıl iken erkek hastaların yaş ortalamas 19.17 $\pm 4,26$ yıl (2-17) yıl ve kız hastaların yaş ortalaması $9,68 \pm 4,53$ yıl (2-17) yıl idi. Hastaların \%60,2'sinde hastalık 10 yaşından önce başladığı ve ortalama hastalık başlama yaşı 8,58 $\pm 3,74$ yıl (2-16) yıl idi. (Tablo 1).

Hastaların \%26,9' unun anne baba arasında yakın akrabalık vardı. Hastaların \% 25,8'inin ailelerinde AAA öyküsü vardı. Hastaların \%21,5 $(\mathrm{n}=40)$ homozigot ve \%67,7 $(n=126)$ heterozigot ve $\% 10,8$ (20) birleşik heterozigot AAA mutasyonu taşıyordu (Tablo 1).

Homozigot, heterozigot ve birleşik heterozigot mutasyon taşıyan hastaların yakınmaları belirlendi. Her üç gruptaki olgularda en sık görülen yakınmaların karın ağrıs1 [sırası ile \%92,5 $(\mathrm{n}=37)$, $\% 92,9(\mathrm{n}=117), \% 90(\mathrm{n}=18)$ ], ateş [sırası ile \% 92,5 $(\mathrm{n}=37), \% 88,1(\mathrm{n}=111), \% 90(\mathrm{n}=18)]$ ve atralji [s1ras1 ile \%17,5 $(n=7), \% 27,8(n=35), \% 15(n=3)]$ olduğu görüldü.

Klinik özelliklerine göre 186 hastamız değerlendirildiğinde $\% 92,5$ karın ağrısı, \%89,2 ateş ve \% 24,2 atralji vard1 (Tablo 2).

Çalışma grubumuzdaki 186 hastanın \% 33,3'ü R202Q, \%22,6's1 M694V, \% 22'si E148Q, \% 7,5'i V726A, \% 4,3'ü R761H, \% 3,8'i M680I, \%1,6's1 M694I, \%1,6's1 A744S, \%1,1'i K695R, \%1,1'i I591T, \% \%0,5 F479L ve \% 0,5'i V33G genotipini taşımaktaydı (Tablo 3).

Tablo 1. MEFV gen mutasyonu pozitif olan hastaların demografik verileri

\begin{tabular}{lcc}
\hline & $\mathbf{n}$ & $\%$ \\
\hline Cinsiyet (E/K) & $84 / 102$ & $45,2 / 54,8$ \\
Yaş (Yıl) & $9,45 \pm 4,40$ & \\
On yıl altı Başlama Yaşı (yıl) & $8,58 \pm 3,74$ & \\
On yıl altı Başlama yüzdesi & 112 & 60,2 \\
Aile öyküsünde AAA & 48 & 25,8 \\
Akraba Evliliği & 50 & 26,9 \\
Homozigot & 40 & 21,5 \\
Heterozigot & 126 & 67,7 \\
Birleşik Heterozigot & 20 & 10,8 \\
\hline
\end{tabular}

AAA: Ailevi Akdeniz ateşi
Tablo 2. MEFV geni mutasyonu taşıyan hastaların klinik bulguları

\begin{tabular}{lcc}
\hline & $\mathbf{n}$ & $\%$ \\
\hline Karın ağrısı & 172 & 92,5 \\
Ateş & 166 & 89,2 \\
Atralji & 45 & 24,2 \\
\hline
\end{tabular}

Tablo 3. Hastaların MEFV gen mutasyon analizi sonuçları

\begin{tabular}{lcc}
\hline Mutasyon Tipi & $\mathbf{n}$ & \% \\
\hline R202Q & 62 & 33,3 \\
M694V & 42 & 22,6 \\
E148Q & 41 & 22 \\
V726A & 14 & 7,5 \\
R761H & 8 & 4,3 \\
M680I & 7 & 3,8 \\
A744S & 3 & 1,6 \\
K695R & 3 & 1,6 \\
M694I & 2 & 1,1 \\
I591T & 2 & 1,1 \\
F479L & 1 & 0,5 \\
V33G & 1 & 0,5 \\
\hline
\end{tabular}

\section{TARTIŞMA}

Ailevi Akdeniz ateşi (AAA) tekrarlayıcı ve otozomal resesif geçişli bir inflamatuar hastalıktır [11]. AAA hastalığının etiyolojisinde rol oynayan $M E F V$ genindeki mutasyonların sayısı ve çeşidi toplumlar arasında değişiklik göstermektedir [12-15] Hastalık evrensel değil, etnik kökene dayalıdır [16]. Türkiye'de hastalığın prevalansı $1 / 1000$, taşıyıcı oranı ise $1 / 5$ 'tir $[12,17]$. AAA'li hastaların büyük çoğunluğunda semptomlar çocukluk döneminde başlar [18]. Majeed ve ark. [19] AAA' lı hastaların yaklaş1k \%80'in de, Gedalia ve ark. [20] ise \%60'ında hastalığın 10 yaşından önce başladığını belirtmişlerdir. Türkiye AAA çalışma grubun 10 geniş serili çalışmasın da hastalık başlangıç yaşı 9.6 yıl olarak bildirilmiştir [21]. Mimouni ve ark. yaptıkları çalışmada Türkler de hastalığın başlama yaşını 12.3 yıl olarak tespit etmişlerdir [22]. Yapılan bir diğer çalışmada hastaların \%79,3'nün klinik bulguları 18 yaş altında başladığ 1 ve klinik bulguların başlama yaş ortalaması 12,4 olarak bulmuşlar [23,24]. Bizim çalışmamızda hastaların \%60,2'sinde hastalık 10 yaşından önce başladığı ve klinik bulguların başlama yaş1 $8,58 \pm 3,74$ yıl olarak bulundu. 
Cinsiyetler açısından dağılım değerlendirildiğinde hastalarımızın \% 45,2'si erkek, \% 54,8'i kız idi. Erkek / kız oranı 0,82 bulundu. Bu oran Türk AAA çalışma grubunun 1,2:1 oranı ile karşılaştırıldığında kız cinsiyetin baskınlığ 1 görülmekte olup Majeed ve arkadaşları tarafından 476 Arap kökenli AAA hastası çocukta bulunan \%54 kız, \%46 erkek oranı ile uyumlu idi $[19,25]$.

Türkiye AAA çalışma grubunun çalışmasında hastaların \%57,3'ünün yakın akrabalarında AAA, \%18,9'unda akraba evliliği hikâyesi vardı [21]. Yapılan başka bir çalışmada hastaların \%20,1'inin yakın akrabalarından AAA, \%18,9'unda akraba evliliği hikâyesi vardı [23] Bizim olgularımızın \%26,9'unun yakın akrabalarında AAA, \% 25,8'inin akraba evliliği hikâyesi vardı. Bu durum Türkiye AAA çalışma grubunun çalışmasına göre akrabalarında görülme oranı düşük ancak akraba evliliği yüksek bulundu.

Ateşle birlikte tekrarlayıcı karın ağrıları en sık semptomlardan biridir. Türk AAA çalışma grubunun sıkl1k sırasına göre şikâyetler; karın ağrısı $(\% 93)$, ateş $(\% 91,3)$, artrit $(\% 58,3)$, gögüs ağrıs1 $(\% 4)$ ve erizipel benzeri döküntü $(\% 2,1)$ olduğu belirtilmiştir [21]. Yapılan diğer çalışmalarda da başvuru şikâyetleri arasında ilk sırada karın ağrısı ve ateş olduğu bildirilmektedir [23-29]. Bizim çalışmamızda başvuru nedenler arasında sıklık sırasına göre karın ağrısı $(\% 92,5)$, ateş $(\% 89,3)$ ve eklem ağrıs1 $(\% 24,2)$ olarak belirlendi.

AAA tanısında kullanılabilecek belirli bir laboratuar testi henüz yoktur. Günümüzde bu tanı klinik bulgular, etnik köken, aile hikâyesi ve kolşisine yanıt gibi tamamen klinik verilere dayanılarak konulmaktadır [30]. Son yıllarda mutasyon analizleri de klinik tanıyı desteklemek amacıyla yaygın olarak kullanıma girmeye başlamıştır. Yapılan çalışmalarda Türk toplumunda en sik mutasyon oranının M694V genine ait olduğu saptanmıştır. Ülkemizde AAA çalışma grubu tarafından 2005 yılında yapılan çalışmada; gen mutasyon analizi yapılan hastaların en s1k M694V (\%51,4), M680I $(\% 14,4)$, V726A $(\% 8,6)$ bulunmuştur [21,31]. Bir diğer çalışmada en s1k olarak M694V $(\% 67,2)$ genine ait mutasyon saptanırken diğerleri sırasıyla V726A $(\% 15,5)$, M680I (\%12), M694I $(\% 5,1)$ olarak bulunmuştur [32]. Başka bir çalışmada ise E148Q $(\% 30,8)$, M694V (\%18.3), P369S (\%10.6), V726A (\%8.6),
A744S (\%2.9), R761H (\%2.9), M694I (\%1.9), K695R (\%1.9) ve I692del (\%1.0) olarak bulunmuştur [33]. Bizim çalışmamızda sıklık sırasına göre R202Q (\% 33,3), M694V (\%22,6), E148Q (\% 22), V726A $(\% 7,5)$, R761H $(\% 4,3)$, M680I $(\% 3,8)$ ve diğer $(\% 6,5)$ mutasyonlar yer almıştır. Çalışmamızda M694V gen mutasyonu diğer çalışmalara göre düşük bulunurken R202Q gen mutasyonu yüksek bulundu.

Homozigot genotipine sahip hastalarda hastalığın daha ciddi formunun görüldüğünü bildiren çalışmalar olmasına [34,35] rağmen aralarında anlamlı bir fark olmadığını bildiren çalışmalarda vardır [36,37]. Çalışmamızda mutasyon tipi ile klinik semptomlar arasında bir fark olmadığı görüldü.

Olguların retrospektif olarak incelenmesinde artrit ve kızıla benzer döküntü gibi semptomların kayıtlarına rastlanmamış olması bu çalışmanın s1nırlılığını oluşturmaktadır.

Sonuç olarak, benzer klinik bulgularına sahip olmakla birlikte ülkemizde yapılan çalışmalarda M694V gen mutasyonunun en s1k gözlenen mutasyon olmasına rağmen bizim çalışmamızda en s1k R202Q gen mutasyonunun olduğu belirlendi. $\mathrm{Bu}$ durum hastalarımızın etnik köken belirtilmemiş olsa da Anadolu'da pek çok etnik grubun varlığından kaynaklanmış olabilir ve bu bize AAA için bir genetik heterojenite varlığını düşündürmektedir.

\section{KAYNAKLAR}

1. Çobankara V, Kiraz S. Ailesel Akdeniz Ateşi. Hacettepe Tıp Dergisi 2000;31:310-319.

2. Barakat MH, Karnik AM, Majeed HW, et al. Familial Mediterranean fever (recurrent hereditary polyserositis) in Arabs study of 175 patients and review of the literature. Q J Med 1986;60:837-847.

3. Çakmak E, Ece A, Kelekçi S, ve ark. Ailesel Akdeniz ateşli çocuklarda atak sırasındaki ve ataksız dönemdeki akut faz yanıtlarının karşılaştırılması. J Clin Exp Invest 2013;4:213218.

4. Direskeneli H, Ozdogan H, Korkmaz C, et al. Serum soluble intercellular adhesion molecule 1 and interleukin 8 levels in Familial Mediterranean Fever. J Rheumatol 1999;26:9831986.

5. The international FMF Consortium: Ancient missense mutations in a new member of the RoRet gene family are likely to cause FMF. Cell 1997; 90: 797-807.

6. The French FMF Consorsium. Candidate gene for familial Mediteranean fever. Natur Genet 1997;17:25-31. 
7. Drenth JPH, Van Der Meer JW. Hereditary periodic fever. N Engl J Med 2003;345:1748-1757.

8. Kastner DL. The genetic of inflammation. Hosp Prac 1998;33:131-146.

9. Mor A, Gal R, Livneh A. Abdominal and digestive system associations of familial Mediterranean fever. Am J Gastroenterol 2003;98:2594-604.

10. Touitou I, Lesage S, McDermott M. et al. Infevers: an evolving mutation database for auto-inflammatory syndromes. Hum Mutat. 2004;24:194-198.

11. Saatçi Ü, Bakkaloğlu A, Özen S, Beşbaş N. Familial Mediterranean and amyloidosis in children. Acta Paediatr 1993;82:705-706.

12. Bakkaloglu A. Familial Mediterranean fever. Pediatr Nephrol 2003;18:853-859.

13. Mansour I, Delague V, Cazeneuve C, et al. Familial Mediterranean fever in Lebanon: mutation spectrum, evidence for cases in Maronites, Greek orthodoxes, Greek catholics, Syriacs and Chiites and for an association between amyloidosis and M694V and M694I mutations. Eur J Hum Genet 2001;9:51-55.

14. Daniels M, Shohat T, Brenner-Ullman A, Shohat M. Familial Mediterranean fever: High gene frequency among the non-Ashkenazic and Ashkenazic Jewish populations in Israel. Am J Med Genet 1995;55:311-314.

15. Dundar M, Emirogullari EF, Kiraz A, et al. Common Familial Mediterranean Fever gene mutations in a Turkish cohort. Mol Biol Rep 2011;38:5065-5069.

16. Goldfinger S.E. Colchicine for Familial Mediterranean fever. (Letter) New Eng J Med 1972; 287:1302.

17. Tunca M, Akar S, Onen F, et al. Turkish FMF Study Group. Familial Mediterranean fever (FMF) in Turkey: results of a nationwide multicenter study. Medicine (Baltimore) 2005;84:1-11.

18. Gershoni Baruch R. Familial Familial Mediterranean fever: Clinical and genetic characterization in a mixed pediatric population of Jewish and Arab patients. Pediatrics 1999;103: e70.

19. Majeed HA, Rawashdeh M, el-Shanti H, et al. Familial Mediterranean fever in children: The expanded clinical profile. QJM 1999;92:309-318.

20. Gedalia A, Adar A, Gorodischer R. Familial Mediterranean fever in children. J Rheumatol Suppl 1992;35:1-9.

21. Turkish FMF Study Group. Familial Mediterranean fever in Turkey; Results of a nationwide multicenter study. Medicine 2005;84:1-11.

22. Mimouni A, Magal N, Stoffman N, et al. Familial Mediterranean fever: effects of genotype and ethnicity on inflammatory attacks and amyloidosis. Pediatrics 2000;105:E70.

23. Solak M, Yıldız H, Köken R, et al. Ailevi Akdeniz atesi ön tanisi alan 165 olgunun $M E F V$ geni mutasyonlarinin incelenmesi. Turkiye Klinikleri J Med Sci 2008;28:117-122.
24. Ergüven M, Üçel R, Cebeci AN, Pelit M. Ailevî Akdeniz ateşinin demografik, klinik ve genetik özellikleri ile tedaviye yanıtı: 120 vakalık tek merkez deneyimi. Çocuk Sağlığı ve Hastalıkları Dergisi 2006;49:283-290.

25. Ozen S, Demirkaya E, Amaryan G, et al. Results from a multicentre international registry of familial Mediterranean fever: impact of environment on the expression of a monogenic disease in children. Ann Rheum Dis 2014;73:662667.

26. Örün E, Yalçınkaya F. Türk tıbbında ailevi Akdeniz ateşi hastalığ1 ve amiloidoz. Nefroloji Diyaliz ve Transplantasyon Dergisi 2003;12:1-7.

27. Çiler Erbağ Ç, Akın Y, Ağızkuru T, ve ark. Ailesel Akdeniz Ateş tanılı olgularımız. Kartal Eğitim ve Araştırma Hastanesi T1p Dergisi 2008;19:131-137.

28. Koné Paut I, Dubuc M, Sportouch J, at al. Phenotype-genotype correlation in 91 patients with familial Mediterranean fever reveals a high frequency of cutaneomucous features. Rheumatology (Oxford) 2000;39:1275-1279.

29. Rawashdeh MO, Majeed HA. Familial Mediterranean fever in Arab children: the high prevalence and gene frequency. Eur J Pediatr 1996;155:540-544.

30. Nir-Paz R, Ben-Chetrit E, Pikarsky E, ve ark. Unusual presentation of familial Mediterranean fever: role of genetic diagnosis. Ann Rheum Dis 2000;59:836-838.

31. Giancanehttp://ard.bmj.com/content/early/2015/01/27/ annrheumdis-2014-206844.full - aff-1 G, Haar NT,Wulffraathttp://ard.bmj.com/content/early/2015/01/27/annrheumdis-2014-206844.full - aff-1 N. et al. Evidencebased recommendations for genetic diagnosis of familial Mediterranean fever. Ann Rheum Dis 2015;10:1-7.

32. Yalçınkaya E, Güran Ş, Nas B, ve ark. Ailesel Akdeniz ateşi ön tanısı alan olgularda $M E F V$ gen analiz sonuçlarının önemi. Erciyes T1p Dergisi 2006;1:19-24.

33. Evliyaoğlu O, Bilici S, Yolbaş İ, ve ark. Diyarbakır yöresi ailevi Akdeniz ateşli çocuklarda $M E F V$ gen mutasyon sıkl1klar1. Dicle Tip Dergisi 2009;36:80-84.

34. Medlej-Hashim M, Delague V, Choueri E, et al. Amyloidosis in Familial Mediterranean Fever patients: correlation with $M E F V$ genotype and SAAI and MICA polymorphisms effects. BMC Med Genet 2004;5:1-6.

35. Padeh S, Shinar Y, Pras E, et al. Clinical and diagnostic value of genetic testing in 216 Israeli children with familial Mediterranean fever. J Rheumatol 2003;30:185-190.

36. Shohat M, Magal N, Shohat T, et al. Phenotype-genotype correlationin FMF: evidence for an association between Met694Val and amyloidosis. Eur J Hum Genet 1999; 7:287292.

37. Cazeneuve C, Sarkisian T, Pecheux C, et al. $M E F V$-gene analysis in Armenian patients with familial Mediterranean fever: diagnostic value and unfavorable renal prognosis of the M694V homozygous genotype-genetic and therapeutic implications. Am J Hum Genet 1999;65:88-97. 